\title{
The Construction of Kekeluargaan as an Indonesia's Organizational Culture
}

\author{
Marko S Hermawan'; Mark K Loo² \\ ${ }^{1}$ International Business Program, BINUS Business School, Indonesia; \\ ${ }^{2}$ Mihalcheon School of Management, Concordia University of Edmonton, Canada \\ Corresponding Email: marko@binus.edu
}

\begin{abstract}
Indonesia has the largest economy in Southeast Asia and the seventh largest GDP in the world, yet little is known about Indonesia's organizational culture. This paper develops a deep understanding of kekeluargaan (kinship), which derives from an anthropological and sociological epistemologies. The paper explores Javanese culture as the foundation of Indonesia's business context. A qualitative and indigenous approach was designed to determine if the kekeluargaan norm exists in the Indonesian workplace today. Document analysis and semi-structured interviews were used to collect data. The findings show that the kekeluargaan norm acts as the foundation of Indonesia's organisational culture; with, hormat (respect) and rukun (harmony). Three proposition are given to consider the importance of understanding kekeluargaan as a salient Indonesian organizational culture. The paper concludes managerial and theoretical implications to Indonesian business context.
\end{abstract}

Keywords: organizational culture; kekeluargaan; respect; harmony; Javanese culture

\section{INTRODUCTION}

The study of Javanese ethnic influence has increased for the past ten years, especially in business context. It is critical to recognize such diverse sources of the discourse that frames interactions in business organizations, to which such discourse often labels as "business culture." One might say it requires an in-depth understanding of its geographical, historical, socio-political, and various cultural contexts before explicating the salient nature of doing business (Baskerville, 2003; Sitorus \& Budhwar, 2003). Another might say that framing such 'culture' within certain interactions, in the context of organizations and align them with routinized attitudes towards authority in the context of Indonesian nationalism, needs to be thoroughly discussed.

Javanese culture and organizational culture is commonly discussed, but failed to scrutize further. Current studies have centralized in scrutinizing Javanese culture as Indonesia's culture origin with leaderships and human resource management (Irawanto, Ramsey, \& Ryan, 2011a, 2011b; Selvarajah \& Meyer, 2017; Selvarajah, Meyer, Roostika, \& Sukunesan, 2016). There is a strong indication that the Javanese norms in heritage the Indonesia social interaction and becoming the 'soul' of modern Indonesian business (Chariri, 2008, 2009; Sarwono \& Armstrong, 2001; Sitorus \& Budhwar, 2003). However, limited studies on Indonesian organizational culture investigate the root cause of ethnic values and norms that are strongly embedded in modern Indonesian business society. Hence, this paper utilizes anthropological epistemology and seeks the way culture concept is embedded within the organization (Bhopal \& Hitchcock, 2001; Irawanto et al., 2011b; Storz, 1999). Following Schein (1990) definition, organizational culture contains artefacts of physical environment of an organization, its products, technology and other patterns of behaviors. He also mentions values of with moral of 
employees, nature and relationships to the environment, in which it does not prone to organizational context. Smircich (1983) argues that organizational culture derives from shared interpretive schemes, expressed in language and other symbolic construction that develop through social interaction'.

We thus initiate a terminology that represents the holistic Javanese norm that has not been fully developed in business context, named kekeluargaan. The term is commonly used and understood as 'Sense of family and kinships' or 'family-principle,' expressed in English (Bertrand, 2015). According to Oxford (1989), kekeluargaan is translated as kindred or kin, whereas under Kamus Besar Bahasa Indonesia (2005), the word defines perihal keluarga or 'about family.' The norm underpins a relationship on filial piety and harmony, which is bound in such a way that connects amongst fellow Indonesian (Magnis-Suseno, 1997). To some extent, this terminology fits closely to the definition of Japanese Uchi society; where the relationship refers to the 'home' and 'family' consciousness in a company (Fujimori, 1993). On the other hand, the concept of Korean Chaebols which defines management conglomerate within a blood relationship (Horak, 2014; Horak \& Taube, 2015), differs from this norm as a close networking.

We argue that such terminology has proven to be shallowly translated, and further explanation is needed to understand the holistic term of kekeluargaan. Nonetheless, the term kekeluargaan extend such term, especially when touching into gaining understanding and commitment to bounds its members within an organization. Thus, this study attempts to contextualize kekeluargaan norm and its application to Indonesian business and management culture. Additionally, this paper materializes traditional components to be used as measurements in contemporary and modern business culture.

\section{THE ROOT OF KEKELUARGAAN: A JAVANESE CULTURE}

The paper starts with the fundamental terminology of culture. Keesing (1974) defined culture as 'systems of socially transmitted behaviour patterns that serve to relate human communities to their ecological settings' (p.75), while Hofstede (1980) defined culture as '... collective programming of the mind... for describing entire societies' (p.13). Another definition compiled by Allaire and Firsirotu (1984) was derived from the cultural anthropology perspective, where they defined culture into two different points of view, namely culture as a sociocultural system and culture as an ideational system.
As a sociocultural system, a culture is a component of the social system, manifested in behaviour or way of life and is a product of behaviour, whereas as an ideational system, culture is a product of minds, in which people share meanings and symbols. This perspective has its origin in the $20^{\text {th }}$ century's anthropology such as the exemplary of the Malinowski's functionalism and the Radcliffe-Brown's structuralist-functionalism. On the other hand, the ideational system was conceptualized by the structuralist school such as Levi-Strauss and the Symbolic school from Geertz's perspective. As a summary, Peoples and Bailey (2011) formulate a formal definition, that culture 'consists of shared, socially learned knowledge and patterns of behaviour' (p. 23).

In defining Javanese culture, we employ the sociocultural approach to understand such phenomenon. We start with explicating the study of Hildred Geertz (1961) on her book "The Javanese Family." At the beginning of the chapter, she describes four basic forms of the Javanese terminology systems: bilateralism, generational, seniority, and gender. The four principles represent a pattern of family ties, which eventually connect to the broader ties in a social context. Bilateralism reflects the two sides of a family; from the father's and the mother's side, while generational illustrates the generation in a family relationship. Father-mother, brother-sister, grandfathergrandmother, and grandson-granddaughter are examples of the two principles. Seniority and gender are the next two principles which differentiate the category of ancestry into a junior or senior level. If someone in the parental generation is a woman, she is called $b u$ or $i b u$, while a man is called pak or bapak. If a woman is considered senior, the appropriate designation is mbak; and if the senior is a man, he is called mas.

The practice of designation towards family ties is also reflected in a wider social context in Javanese culture, where people are treated by their mutual social rank, position, space, and harmony (Magnis-Suseno, 1997). Geertz (1961) posited that the most important dimension for the classification of family members is their proximity to self, and the size of the classification is not apparent in family terminology. This is scrutinized by the work of Anderson (1990) where the Javenese relationships are based on the division of 'Power', that power is a concrete and independent; that power is homogeneus; that power is constant; and that power does not raise the question of legitimacy. Such relationships, thus construct a legitimate, non-transferable, and eternal power between one individual and another.

Koentjaraningrat (1984), in his book of "Javanese Culture", further discusses the collectivist behavior as a 
Javanese, in which he distinguishes the villagers (petani) and the bourgeoise (priyayi). The Javanese believes in a feeling that people are not alone in the world, and that he can always expect help from others, especially the relatives, who otherwise expect the same from them. Thus, he is obliged to maintain good relations with them and his close neighbors, by always paying attention to their needs, as much as possible to share his property with them. The feeling also covers as much as possible to put themselves in their situation, namely tepa selira. As such, the community expects a Javanese to maintain uniformity and harmonious between each other, which sometimes intervenes his personal life.

The Javanese endeavor to treat people with whom they have business or personal relationships as relatives by blood. This also means neighbors must always be treated as relatives. In some occasion, a series of celebrations held throughout the life circle of senior members, as well as ceremonies to intensify solidarity between members of a group of relatives. The Javanese commonly mention mangan ora mangan ngumpul, or eat or without, we gather. This statement changes its meaning and purpose, in that people who leave their villages is prohibited.

Koentjaraningrat (1984) continues to describe village people as having a vertical cultural value orientation. Villagers have respect, views, blessings, and assistance from important people, high-ranking people, civil servants, senior people, and old people in the community. If they are dealing with their boss, they try to avoid difficulties by staying silent or saying kindly, without feeling obliged to account or feel bound to that answer. Similar behaviour occurs in priyayi, where value orientation of the collateralism are vertical oriented with respect to dependent, trusting, and respectful of seniors and superiors (Magnis-Suseno, 1997). Despite of this, Koentjaraningrat (1984) argues they are often not eager to try to take responsibility for themselves.

In her book, Hildred Geertz explained the definition of 'Respect' which is an etiquette between individuals. Kuntjaraningrat (1984) argues that there are differences in interpretation regarding 'Respect.' $\mathrm{He}$ argues that 'Respect' has a level of interpretation that can be felt and practiced by the Javanese, by the context of dealing with counterparts. The diagram below indicates the attitude felt by the Javanese in their manifestations 'Respect'.

A sense of Ajrih for Javanese people is located as an epicenter of fear of others, as a continuum between horizontal and vertical lines of norms. The top level shows feelings towards our superior, while the lower direction shows the inferior nature to others. The horizontal lines, on the other hand, shows positive and negative attitudes towards others. Ajrih positions the meeting point of all Javanese individual feelings and assumes fear concerns his (Ego) state of others. In other words, the Javanese feel awkward towards others when they do not know what others will do to them. The feeling is the same as if people are paralyzed because of their fear of being hurt or being embarrassed by people. In turn, the connection between superiority and inferiority, respect must be placed at the highest, and $i \sin$ the bottom.

Figure 1. Level of Javanese feelings towards others

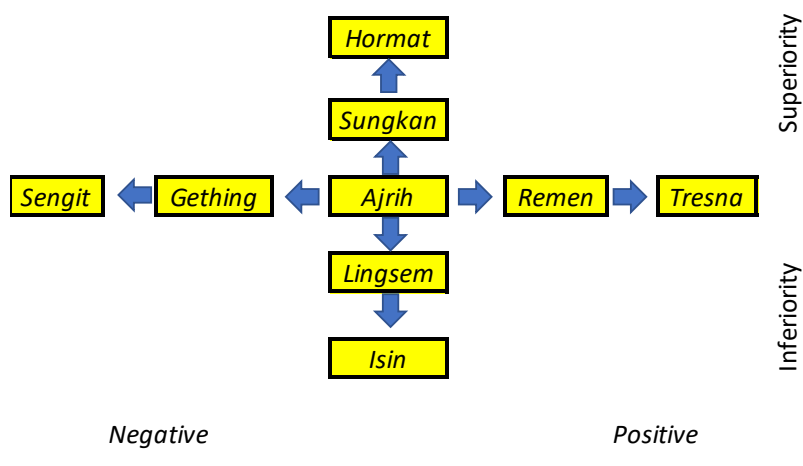

Historically, Javanese parents tend to inculcate both 'warmth' and pessimistic view of life in the world. On one hand, a mother provide 'warmth' for her child for comfort, happiness and protection (Shiraishi, 1997). On the other hand, a child must also perform eling and must concerned about the misery of life. Hildred Geertz (1961) argues that parents intentionally and consciously teach feelings of fear (wedi) to their children and always try to impose their will by scaring children with the threat of punishment by various magical powers. Javanese intentionally teach shame (isin) in certain circumstances and is a clear concept to measure the attitude of Javanese people with each other, so that Villagers highly value behavior that seeks to maintain good relations with others, help others as much as possible, share sustenance with neighbors, try to understand the feelings of others, and a person's ability to live up to other people's feelings (tepa selira). Therefore, children try to approach such qualities.

The level above Isin is Lingsem, commensurate with the meaning of shame. The Javanese feel Lingsem if they feel themselves bad because of one reason and because of that they will try to avoid it so that other people do not get a bad impression on him. Ajrih shows an ego that becomes hesitant and afraid of him and tries not to disturb him. If for some reason the Ego needs to relate to it, the Ego will try to communicate with other 
people. If he is forced to deal directly, then he will do it with reluctance.

On the right of the continuum line line tresna or loving. It is a loving feeling towards other people who they know so well. According to the logic of the Javanese, it is impossible for a person to love someone who is of a higher degree. Herein lies the difference between the tresna concept in Javanese and the European concept. For Javanese, people cannot "love" Allah or the Prophet Muhammad, while in English, people can say to love God or to love Jesus (Koentjaraningrat, 1984).

On the other hand, point to the left of the horizontal continuum, we will enter the area of negative feelings. A Javanese who starts to recognize the characteristics of a person and knows that the person has a bad intention, or makes him embarrassed and even insulting, then he will dislike that person and will have hatred or gething towards that person. This feeling can develop even more negatively, giving rise to a sense of hatred, or fierce.

\section{METHODOLOGY}

The objective of this paper is to explore and reveal the social nature of a salient culture is meant to explore the native perspective of one cultural context, namely Javanese values and their manifestation in the kekeluargaan norm. As C. Geertz (1973) argued, it is important to present a "thick description" which comprises facts, commentary, and interpretation. As the interpretivist paradigm anticipates, a "native point of view' is introduced for the following reasons. First, the indigenous 'paradigm' is considered as a suitable approach, in which one perspective is derived from what indigenous people think, and how things are perceived in their world (Wilson, 2001, p. 175). There has been high interest in indigenous research, particularly in Asian countries, in which epistemology encompasses 'context-sensitive and context-specific approaches to a uniquely local phenomenon or issue in Asia, which may have global implications ' (Horak, 2014; Li, Sekiguchi, \& Zhou, 2016; Porsanger, 2004). Second, there is a growing trend of an indigenous researcher to conduct his/her own cultural context, which constructs a different contextualization and understanding, compared with a non-indigenous observer (Horak, 2014; Meyer, 2006; Tsui, 2004). Much of the context refers to the root of a local culture, which derives behavioral and symbolic values. Such values are best understood when they are interpreted by an indigenous researcher (Tsui, 2004). Moreover, the purpose of the indigenous approach is to ensure for a better understanding in a more respectful, ethical, correct, sympathetic, useful, and beneficial fashion, from the point of view of indigenous peoples (Porsanger, 2004). Being Indonesian born and raised, one of the authors has an advantage of conducting a ethnographic study of Indonesian culture in a way that he is able to reveal innate and subtle Indonesian cultural aspects and norms that may not be discovered by Western studies. Hence, this study can enhance the interesting, yet, rich description of Indonesian norms.

Data collection was gathered in twofold: document analysis and interview analysis. The first stage is an analysis of prior research in Indonesian business, management and organizational cultures is crucial, in order to to give voice and meaning around an assessment topic (Bowen, 2009). The second stage is a semistructured interviews from two institutions: one of the Big4 accounting firms (hereafter referred to as 'KAP') and one private university (hereafter referred to as 'UNIV') located in Jakarta, Indonesia. The two organizations have similar backgrounds, in that both founding fathers and leaders originated from Indo-Chinese descendants, are employed by multi-ethnic staff, and are in Jakarta. Ten interviewees from each institution were gathered using a semi-structured technique. The interviewees were found to be mixed-ethnic and expatriate groups, including Javanese, Minangkabau, Batak, Chinese Indonesian, Filipino, and French. The last two expatriates have been staying in Indonesia for over 5 years, in which they enable to provide comparative analysis between Indonesian culture and their own. The data analysis followed Miles and Huberman (1994) data analysis technique, which all transcriptions were transcribed into text within the same language in order to ensure that all transcriptions of voice tones, expressions, and implicit meaning were fully captured. The patterns and themes were noted, looking at the plausibility, clustering, and sense-making to confirm the logic of meaning.

\section{PROPOSITION TO KEKELUARGAAAN ORGANIZATIONAL CULTURE}

The paper seeks to develop a construct of organizational culture that scrutinize the anthropological epistemology of Javanese. Both references of Geertz (1961) and MagnisSuseno (1997) conclude their work with one salient epistemology in organizational culture: social harmony. In conjunction between culture and organizational culture, we employ definitions organizational culture by Langton, Robbins, and Judge (2013) to define 'a system of shared meaning held by members that distinguish the organization from another' (p. 352). The duo-impetus 
of hormat and rukun, which consist of bapakism, isin, gotong-royong, and musyawawah mufakat are the fundamental of kekeluargaan. Magnis-Suseno (1997) argued that any ethical and moral considerations will fall under the two impetuses, and no one is to confer 'the right to disregard the principles of harmony' (p. 74). Hence, the following section offers a proposition of kekeluargaan within a business context.

\section{Proposition 1: A typology of Kekeluargaan organizational culture}

The scrutinizing the existing Javanese literature by Geertz (1961), Magnis-Suseno (1997), and Koentjaraningrat (1984), and organizational culture definition by Smircich (1983) and Schein (1990), we propose two basic principles of Javanese social life: Hormat and Rukun. Geertz (1961) posited that the most important dimension for the classification of family members is their proximity to self, and the size of the classification is not apparent in family terminology. To scrutinize its proximity to a specific social relationship she argues, "I hypothesized that the most important of the special social relations concluded by family terms as used between each of the two-family members was respect and harmony."

\section{Hormat (Respect)}

Hormat in the Javanese expression defines a belief that all social relationships are hierarchically ordered, and the moral imperative to maintain and express this mode of social order is a good [act] in itself (Geertz, 1961, p. 147). The attitude of respect is a guiding behavior in a range of contexts; government officials, children in schools, political parties, amongst neighbors, and more. It is imperative for a Javanese to observe a counterpart and ask, "What degree of respect should I show him?". We devide Hormat into 2 categories: Bapakism and Isin.

\section{Bapakism}

Within this scope, Javanese culture is also the behavior of Bapakism which reflects the form of paternalism and patronage (H. Geertz, 1961; Lewis, 2006). The original word, Bapak, is defined as a father, a charismatic figure who commands respect, obedience, and loyalty from subordinates (Efferin \& Hopper, 2007). Bapakism requires society to respect older persons, a norm that applies to the family and manifests extensively in Javanese social life (Rademakers, 1998). The online dictionary of the Indonesian language (KBBI, 2005) defines Bapakism as the practice of leader and subordinate relationships that mimic the pattern of father and child relationships. It is also the habit of glorifying the leader (boss). The value of Bapakism cannot be separated from the socio-class strata in Javanese life.

Within the business context, the manifestation of Bapakism can be seen from the following conversation. The Bapak (Father) is represented by a leading role of a person, that is the highest leader in the company. In this case, the reflection of Bapak is the founder of the company or institution which has a significant influence on its environment and organizational culture. The bapakism value is an extension to family boundaries and must show a strong role of power, authority, and legitimacy (Irawanto et al., 2011b; Selvarajah et al., 2016).

I created my own culture, my own style of management ... I created my own culture in that sense of accountability, we are very accountable ... That is the culture I created and that is what they like. Until today, I still hear my old partners saying, "Mr. U [the founder's name], I think this is the right system because we have got the freedom but also get [our] clients (Founder).

The second conversation confirms that Bapakism is a reciprocal relationship between the leader and the staff, in which they have a 'role' like a father and a child. If a leader can apply fatherly principles, then staff will usually adjust to becoming a child. As a result, the atmosphere of the company like this will create high loyalty and harmony in work.

The value that has strongly been [passed] by the founder. And now it can be said that the second generation [can] experienced [by] themselves. [I] experienced how it is like being with the founders... Because it can be said that when our founder applied the principles that still has the "Indonesian" here... As for how I see, with current lead generation, the founders' influence, the founder's principles are still there (Senior Management A).

The reason why I don't want to leave this firm is that of the strong values our founder has given. The second generation is [currently] running the business and they too have the values ... If I can observe the current generation, the founder's principle is still intact [in the firm] (Senior Management B).

We are glad to work in this place. We feel that our leaders [Board of Directors] have values that are derived from their founding father. That's what makes this university strong (Lecturer). 
Another example to reflect Bapakism in business is to initiate a meeting arrangement, where having 'the right' people is important (Perks \& Sanderson, 2000). Indonesians are concerned with the people you meet up with; they will look at your age, seniority, and experience, before continuing to the discussion.

\section{Isin and Sungkan}

Isin, on the other hand, is the lowest rank of inferiority towards others. As stated by Koentjaraningrat (1984) Isin distinguishes addresing a proper self-positioned manner, by providing a 'positive and negative' feelings upon proper attitude to others. Magnis-Suseno (1997) describes "Isin is to feel ashamed, as well as shy, to feel embarrassed, to feel guilty and the like." (p. 66). A person shows his/her Isin when they are unable to show a sufficient degree of respect towards individual who commands a high order of it. On the other hand, Sungkan is a more common word to use in the society, which represent "positive shyness which one experiences in the presence of one's superiors" (p. 67). H. Geertz (1961) illustrated Sungkan as a feeling of respectful politeness before a superior or an unfamiliar equal.

In a business context, both Isin and Sungkan are interwoven, in that being respectful to supervisors and/ or seniors must show proper attitude. They become critical when these norms interrupted organisational systems. Most Indonesians working in this organisation are aware of the way to express thoughts by going through the proper procedures; either to express concerns, disagreements, or objections to the management. Unfortunately, this procedure is not really an effective means of communication. Instead, a person feel sungkan to a supervisor when he/she needs to react upon his/her supervisor.

The culture in [this organization] is busier ..., more overtime. The overtime sometimes doesn't make sense, because the culture we have is you wait for the seniors to go home, while here the division of labor is more specific; you [are the] assistant, you [do] this job (Employee).

Of course, it will always be like that. If I say, for example, there is something you dislike, you'd better talk directly, rather than to talk behind someone's back. But sometimes people are hesitant [to speak directly] (University Staff).

The two conversations reflect the level of sungkan when faced with a situation of superiority. Here, it is not the Isin attitude that appears, but Sungkan is appropriate.
The attitude of Sungkan regular show hesitant to express his/her feelings to supervisor, or rather, difficult to express in a positive manner. It is within the Javanese culture to await the supervisor reaction, before expressing staff's thoughts, which also creates a subtle communication. The Javanese tend to avoid conflict in a family, and obey the will of the father. Such attitude also reflect in the organization culture.

In a business context, people rarely show their Isin in front of others, too. But the inferior nature is clearly visible, in that a staff will feel 'afraid' to the supervisor. This feeling is different to Sungkan, and the staff will be afraid of the supervisor of his actions

And if for example he is stressed out just because he doesn't know what to ask first ... but at the end of the day, all the data is wrong. Do you know why? Because we have no control and he does not want to ask, ... he's afraid "oh this my senior" and if he asks, he will get scolded (Employee).

Both Sungkan and Isin show a reluctance behavior and create an issue of 'space'. The Indonesian tend to use the 'space' to work according to his time comfort, whereas the expatriate was concerned about the task. A repetitive interference to a person results in avoidance. Furthermore, the appropriate 'procedure' is that a fellow Indonesian would speak to another Indonesian and not try to confront the expatriate. Such a feeling of insecurity produces a 'bypass' in communication to others, both formally and informally. Consequently, the 'chain of conversation' creates rumors of fear to a person whom they consider invading their 'space'.

\section{Rukun (Harmony)}

The second Javanese value is rukun, which can be interpreted as the maintenance of social harmony (Geertz, 1961, p. 148). Being 'harmonious' infers a person is able to control any negative impulses by managing emotional equilibrium in stasis and to be aware of any reverberating emotional responses from others (Magnis-Suseno, 1997). In Javanese society, having rukun avoids conflict, upholds the harmonious agreement, and shows attitudes of calm, peacefulness, and unity, by which a person must respect another's thoughts (Sunaryo, 2010). If there is a disagreement, the individual must not express that in public. Thus, the practice of rukun does not merely reflect mutual agreement but also honors the consensus of a group, without obstacles, and hinders any developing friction. 


\section{Musyawarah Mufakat}

Rukun, as a norm, is manifested as a propensity of collective and unanimous decisions (musyawarah mufakat) and cooperation (gotong-royong) (Efferin \& Hartono, 2015; Efferin \& Hopper, 2007). One value, called musyawarah, represents an equal attitude toward all voices and opinions, in order to establish the totality of a consensus of opinion (Mulder, 2005). Mufakat constitutes the unanimous decisions from the discussion to gain consensus from all members. In a group or community discussion, the aim of musyawarah is to accommodate all views, but no decisions are taken to satisfy only one party. Instead, all decisions are taken by consensus and all participants should be prepared to relinquish and/ or compromise their particular view (Magnis-Suseno, 1997). It is believed that the musyawarah mufakat norm is appropriate for a diverse ethnic society. This norm was also adopted as one of the five principles of the Pancasila national ideology.

The Musyawarah Mufakat starts with a notion of being tolerant. The manifestation of musyawarah mufakat is not only a matter of how well a person communicates and counsels in a discussion but also the behavior of being tolerant, in which it has been demonstrated over centuries to welcome differences of religions.

The idea of toleransi (the degree to tolerate), as such, is inextricably associated with the peculiar nature of religion in Java... In brief, the crucial factors to be taken into account if one is assessing the degree of real religious tolerance in any particular case are the ethnic and class associations of the relevant religious group. One should not argue that the Javanese are tolerant of Christianity and 'Buddhism' as such, but insofar as these religious systems have been assimilated to 'Javanism' and to the extent that their adherents are respectable Javanese (Anderson, 1965, pp. 2-4).

The above notion confirms that being tolerant is becoming part of the societal interactions, in particular for the Javanese. In this sense, the finding suggests that musyawarah mufakat is merged into the behavior of being tolerant of others.

Another implementation of musyawarah mufakat in business society is seen from the quotation below:

...the committees are actually intended to build better control. However, since the establishment of committees has been part of a trend in implementing the practice of good corporate governance, we decided to make some executive committees. On these committees we decide everything together. (emphasis added.) (Chariri, 2009, p. 53).

The word 'together' reflects a notion of having togetherness in decision making within the organization. In some way, all decisions must be inlign with the leader, while reaching collective consensus. Indonesian are aware on this norm and are avoiding conflict in the process. Hence, musyawarah mufakat intends to dominate the agenda during meetings.

\section{Gotong-royong}

The other value, gotong-royong, denotes mutual assistance and the sharing of burdens (Mulder, 2005). It is described as mutual assistance, where one is helping one another when building a house or preparing a family celebration in a village. The nature of helping one another without ulterior motives is manifested in Javanese people, and it is believed to maintain good relationships amongst others (Magnis-Suseno, 1997).

In a business context, one example of gotong royong is reflected into a feeling of empathy to others, or by helping others to relief ones problem.

For example, while working, there is a person who asks "Can I leave the office?" As long as there is a good reason for that, we give [permission]. But it turns out to be, for example, "My mother is ill, I have to take her to , blah, blah, blah", we tend to feel sympathy in such an instance (Employee, Female).

Expressions of sympathy and empathy are very strong among all Indonesian people. The attitude of providing relief and offering assistance to others are a manifestation of Gotong Royong or mutual aid.

Figure 2. A Typology of Kekeluargaan

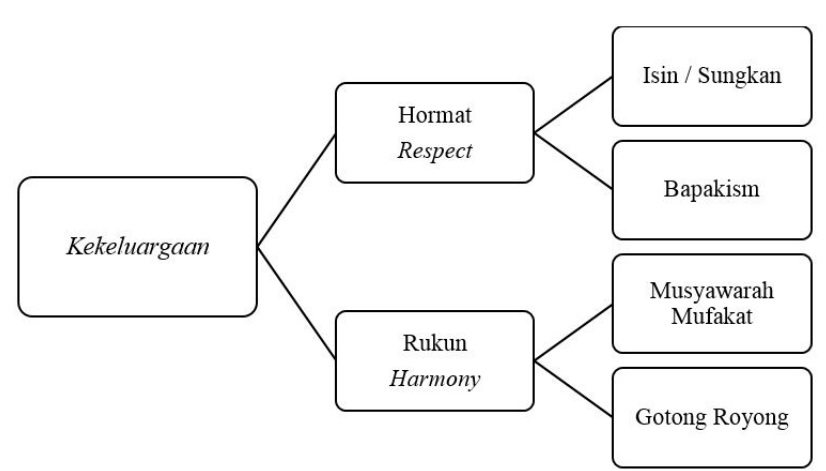


From the above description, we proposes a kekeluargaan organizational culture framework as shown in Figure 2. The framework describes a complete intention of norms that reflects kekeluargaan in an organization.

\section{Proposition 2: Hormat and Rukun are an inter-connected business networking}

The duo-impetus of respect and rukun, which consist of bapakism, isin/sungkan, gotong-royong, and musyawawah mufakat are basis of kekeluargaan. Magnis-Suseno (1997) argued that any ethical and moral considerations will fall under the two impetuses, and no one is to confer 'the right to disregard the principles of harmony' (p.74). This section offers a diagram on how respect and rukun are interwoven.

Figure 3. Interactions between Rukun and Respect

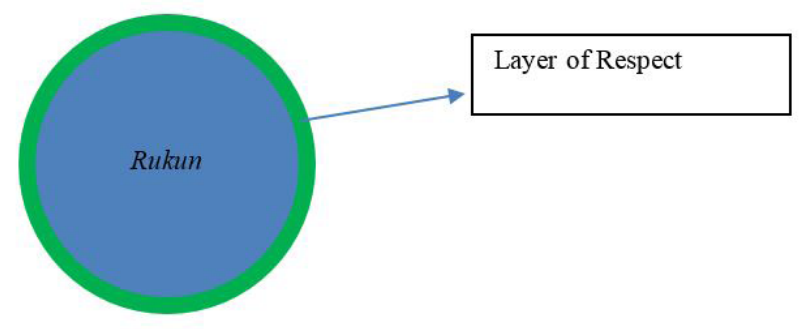

The diagram starts from a notion of an individual being secured in a 'comfort zone'. Figure 2 depicts how the Javanese family is shaped by the two Javanese principles: rukun and respect. Magnis-Suseno (1997) illustrated that the "rukun principle regulates all forms of non-authoritarian decision making, [while] the principle of respect determines hierarchical relationships and, thereby, lays out the frame for possible interactions (p.72)". On one side, one must have a position of a rightful and comfort place in a way that decision making, and consensus has to be made in accordance with the rukun value (illustrated by the blue shade). On the other hand, the respect is purposed to construct the "the hierarchical frame of reference and thereby determines the greatest portion of the possible ways of making a decision, namely those of an authoritative nature (p.72)" (illustrated by the green border circle). The most distinct characteristic to address rukun and respect is the honorific bapak (father) or $I b u$ (mother) accorded to older or married colleagues (respect), and this honorific title greatly reduces hierarchical distance (rukun). This is in accordance with the norm in which neighbors, for example, must be treated as relatives. Hence, the commonalities of a family are reflected in the society as well.
To a larger extent, kekeluargaan is proved to exist in such organizational culture and business practices. What is mentioned so far is that the manifestation reflected in the 4 main areas are found in most local firms and public sectors. The strong values of bapakism, patriotism, and nationalism contribute significantly to the development of kekeluargaan. Bhinneka Tunggal $I k a$; unity of diversity, has proven to be an effective ideology to unite Indonesia, in which kekeluargaan acts as the 'adhesive' of Indonesia's social construction. Different with the Guanxi concept, where such ties between members are based on deliberate networking, such as mianzi (face), affection and reciprocal favor (Lin, 2011), the establishment of kekeluargaan is derived from common grounds of tolerance, empathy, and informal connectivity. Each member does not intend to establish a reciprocal bond, but rather a common understanding of harmony. As such, rukun is the fundamental and subtle 'layer' that underpins every aspect of the society, as well as business practices.

On the other hand, 'respect' forms a rather hierarchical structure within the Indonesian society, which is in line with the works of Geertz (1961) and MagnisSuseno (1997). In business practices, such hierarchies are shown in relation to establishing networking. This phenomenon extends a proposal of analogy: circle 1 represents the Javanese manifestation towards respecting or sungkan to its outer layers, and circle 2 demonstrates a similar attitude within a business networking context, as shown in Figure 3.

Figure 4. The Analogy of Kekeluargaan networking

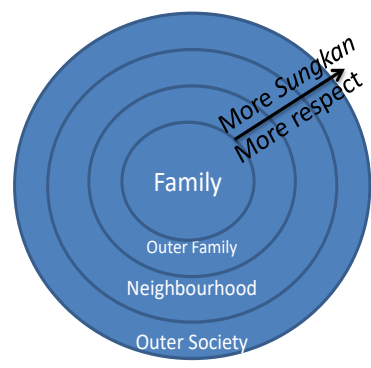

Circle 1

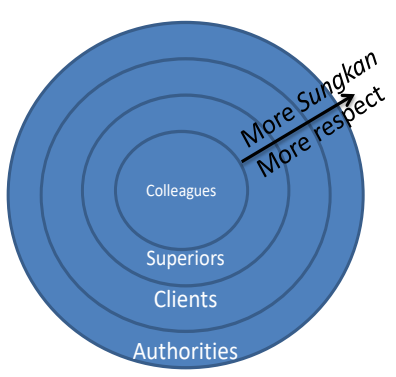

Circle 2
Circle 1, as illustrated by H. Geertz (1961), reflects the degree of respect towards the layers of a community. The inner family, which lies in the most inner circle has the most harmonious and the least sungkan or shyness amongst its members. The outer family is an extension of the core family, such as grandparents, older fathers/ mothers. The inner family may have higher sungkan 
and respect to this layer. The neighborhood is the next layer, where the feeling of 'sungkan' is stronger than in the previous circles. The outer layer is society, where relationships are furthest from the family and respectful attitudes are highly valued. Thus, the more removed a person is from the central family unit, the more a person must respect others.

Circle 2, on the other hand, proposes an analogical behavior in Indonesian business culture. It involves the inner-relation between close colleagues and their behaviors to an outer-organisation. The level of respect or sungkan increases as soon as the staff members interact with their supervisors. This generates a more respectful behavior towards managers until directors as superiors. In the outer organization, the relationship towards the 'client' continues to show more distance of respect which results in greater respect but tends to be at the 'lower' level than its client. The manifestations of the Javanese 'respect' are shown to be higher at each level of the hierarchical networking, until government authorities. The utmost relationships to this layer are exhibited as a priyayi; a high-ranking member of an authority or in some cases, someone who is chosen by the government to be positioned as a regulator in government agencies (Irawanto et al., 2011a, 2011b). A high level of bapakism is shown when interacting with government agencies, as a sign of respect. This explains why most of the problematic factor in Indonesia lies on inefficient government bureaucracy (LaVan \& Murphy, 2007). On the other hand, a person that is considered 'below' the rank of an officer will perform an attitude of nrimo (acceptance), which emphasizes accepting one's status with respect (Irawanto et al., 2011a).

\section{Proposition 3: Kekeluargaan is a salient norm which differ from another Asian business norm}

All illustrations differentiate kekeluargaan from the other terms of culture of Uchi, Guanxi, and Yongo. Although the collectivist content is strongly described, the inclination towards tolerance, permissiveness, and empathy does not reflect the above terminologies. It has a degree to which kekeluargaan prioritizes the feeling to put oneself in 'someone's shoes' or even becomes the counterparty's role. In a business context, such an occasion can be time-consuming, knowing that Indonesians tend to decide collectively, and tend to be indecisive (Perks \& Sanderson, 2000).

In comparison to other Asian terminology, the principle lies in the fact that the Javanese inner family is a concept of 'protecting the member' (H. Geertz, 1961). Compared with the Korean Yongo, which emphasizes the connectivity of members within a business management (Horak, 2014), less evidence shows that kekeluargaan has nothing to do with family interests. Nor is it related to such comparison to the Japanese Uchi, where the form is based on a long-term give-and-take principle (Fujimori, 1993). This norm is a non-reciprocal action, wrapped in a subtle connection of the relationship, and it becomes a

Table 2. Comparison of Kekeluargaan and Other Terminology

\begin{tabular}{|c|c|c|c|c|}
\hline Category & Kekeluargaan & Uchi & Huanxi & Yongo \\
\hline Root Metaphor & Family & Home & $\begin{array}{c}\text { Family, University, and } \\
\text { region-based ties }\end{array}$ \\
\hline $\begin{array}{c}\text { Sources of } \\
\text { Legitimacy }\end{array}$ & $\begin{array}{c}\text { An inner } \\
\text { relationship of a } \\
\text { family }\end{array}$ & $\begin{array}{c}\text { Dividing people } \\
\text { into in-groups and } \\
\text { out-groups }\end{array}$ & $\begin{array}{c}\text { Formal and informal } \\
\text { exchanges, developing } \\
\text { networks of mutual trust } \\
\text { and interdependence }\end{array}$ & $\begin{array}{c}\text { Predetermined by } \\
\text { birth or university } \\
\text { affiliation, not voluntary } \\
\text { participation }\end{array}$ \\
\hline Sources of Identity & $\begin{array}{c}\text { People's } \\
\text { interactions }\end{array}$ & $\begin{array}{c}\text { Long-term give- } \\
\text { and-take principle }\end{array}$ & $\begin{array}{c}\text { Social respect, dignity, } \\
\text { and public image }\end{array}$ & $\begin{array}{c}\text { Connection to kin, } \\
\text { educational institution, } \\
\text { region }\end{array}$ \\
\hline Basis of Norms & $\begin{array}{c}\text { Rukun and } \\
\text { Respect }\end{array}$ & $\begin{array}{c}\text { Mutual relationship } \\
\text { is formed into } \\
\text { cash/non-cash } \\
\text { affiliations }\end{array}$ & $\begin{array}{c}\text { Mianzi (face), affect and } \\
\text { reciprocal favor }\end{array}$ & $\begin{array}{c}\text { Flexibility, tolerance, } \\
\text { mutual understanding, as } \\
\text { well as trust }\end{array}$ \\
\hline $\begin{array}{c}\text { Sources of } \\
\text { Authority }\end{array}$ & Leader's value & $\begin{array}{c}\text { Seniority is evident } \\
\text { and }\end{array}$ & $\begin{array}{c}\text { Family business } \\
\text { relationship }\end{array}$ & $\begin{array}{c}\text { Apparent and exclusive } \\
\text { network }\end{array}$ \\
\hline
\end{tabular}


boundary of a sub-institution within a formal institution Based on the finding, the two organizations demonstrate a strong sense of kekeluargaan, in that both institutions have similar outcomes to such networking. Kekeluargaan is thus shaped not by the management and organizational culture; it begins with the actor's self-manifestation and connects with subtle 'layer' of similar understanding amongst others. Such connectivity produced is based on the two norms: rukun (harmony) and hormat (respect).

Table 2 illustrates kekeluargaan compared with Uchi, Guanxi, and Yongo. The y-axis category is adopted from Institutional logics perspective initiated by Thornton, Ocasio, and Lounsbury (2012), where categorical elements are driven by an interpretation of material and symbolic aspects of an institution.

There are several important aspects on this proposition. On a fundamental basis, kekeluargaan is an acculturation of several interpretation in various ethnic groups, which becomes a common norm to Indonesians There is an indication that the leader or founder has a strong influence in creating an organizational culture and that the members are considered passive, which supports Efferin and Hartono (2015) argument. Deriving from a root metaphor of "Family", it can be inferred that kekeluargaan exists within the 'grass-roots' level where staff acknowledges the ambiance of closeness and a common understanding of harmony, and comfort and conflict avoidance.

The leader's role is one of the most important elements in the context of kekeluargaan. The value of bapakism as described by Magnis-Suseno (1997) is then mixed with the value of Confucianism, where the leader is an important role to conduct a virtuous corporate life (Ip, 2009). The leader's position as a 'father' in the country remains a critical variable (Irawanto et al., 2011b). Several pieces of evidence support this argument, ranging from politics, as well as economic and social settings The concept of the head of a 'large family' for the people is a metaphor of a Head of State (Rasuanto, 1999). The fatherhood and leader's role can be equated to the fatherson relationship of Confucianism (Lin, 2011), where there is a strong egalitarian norm embedded in the society. The first President, Sukarno, interpreted and implemented kekeluargaan as a spirit to mutual cooperation (gotong royong), whereas his Vice President, Hatta, defined a social and ethical interaction, helping each other to have a mutual understanding (Effendi, 2004; Rasuanto, 1999). Both interpretations are strongly manifested as a reflection of the Javanese rukun and hormat.

In relation to power distance, many bureaucrats may take for granted this value to take advantage of their positions of authority. Providing gifts in honoring or showing respect to the priyayi or in this case, the highest-ranking person, eventually creates patterns of habitual actions in business relationships. Many business participants thus perform this 'ritual' to government agencies to bypass cumbersome and rigid regulations. Javanese values of both harmony and respect remain prevalent in Indonesian daily life and influence many business behaviors (Irawanto et al., 2011a). It is becoming a common practice for many business practitioners (Sitorus \& Budhwar, 2003), and corruption has become embedded in a system which perpetuates a high level of bureaucracy and authoritarian models. Thus, in the current situation, kekeluargaan may not align with Western perspectives to establish effective management performance.

The connectivity of business networking has a different orientation, compared with the Korean Yongo, Yonjul, and Inmaek. As mentioned by Horak (2014), the Korean networking is bound to education, family, or blood, and regional-based ties. To some extent, the Indonesian kekeluargaan, the Korean yongo, and the Chinese Guanxi show similarities in that informal networking exist and its influence towards business networking is immense (Horak \& Taube, 2015; Lin, 2011). Kekeluargaan, on the other hand, is a networking between placing harmony as the fundamental layer and honoring a hierarchicalbased relationship. Both concepts establish a horizontal underpinning and vertical connectivity, respectively, which are intertwined to one another. In every layer, all require subtle communication, harmonious relationships, a comfortable environment, and even empathy amongst individuals. One must understand the complexity of networking that a person is facing and that such a manner pertains to each of the levels of respect.

Towards tolerance and permissive issues, Sitorus and Budhwar (2003) argued that a typical Indonesian business entity is nuanced with inner tranquility, harmony, and stability, as well as collectivism and patronage systems. The values of harmony are found to be a mixture of Javanese rukun and Chinese Confucianism (Efferin \& Hopper, 2007). The predominant values of the Javanese, combined with strong inherent Confucian values from the founding partners, have produced a unique characteristic of office behavior rarely considered to date as an influential dimension of the institutions. Hence, Indonesians prioritize comfort and serenity while working in a group as well as conflict avoidance among members of the group. Punctuality is not considered an important norm, and the Western norm towards efficient time management is sometimes completely omitted. The 
term jam karet, or 'rubber time', is commonly observed: Indonesians do not like to be hurried and there is little sense of urgency about anything (Lewis, 2006; Perks \& Sanderson, 2000), inside or outside the office.

\section{CONCLUSION AND IMPLICATION}

This study offers a salient epistemology of organization and domination of one ethnic group within a nation. There have been vicious Western philosophy and rationalist thinking in studying organizational culture, which may not offer other cultural model perspectives, as far as the Western business research is concerned. There is an increasing number of interests to observe such fields, especially Asian countries. The finding suggests that complexity and a comprehensive understanding of the organizational culture are imperative and unavoidable. This study underpins the foundation of Indonesia's organization culture, in which kekeluargaan acts as one of the ubiquitous norms in Indonesia. The notion of family and a collectivist attitude, albeit similar, is proven differently as far as the cultural background is concerned. Indonesia, as many other Southeast Asian nations, offers a complex, yet, unique field of business prospectus. Elements such as the founder's values, kekeluargaan, tolerance, and ethnic backgrounds, are some of the drivers not discovered in Western studies. Thus, we offer a valuable alternative view in understanding Indonesian business in relation to contextualizing networking systems and culture.

The study offers theoretical, as well as practical implications. This research introduces a constructive approach to identify factors contributing the formation of Indonesian business culture, which derived from a Javanese perspective. The two values of Rukun and Hormat are fundamental concepts to underpin the business communication and organizational culture of Indonesian society. An indigenous qualitative study of ethnicities and cultures, enables a more comprehensive understanding of cultural diversity on business practices. A relevant epistemology with an indigenous approach provides a different angle of the culture, in which kekeluargaan appears in nature within a society and hierarchical structure. It represents the enacted value of the rational behavior and manifestation that represent the true color of Indonesia.

Practically, as many indigenous researchers flourish in Asian countries, this study enriches various cultural contexts in business practices within the region. Kekeluargaan, on the other hand, involves subtle communication and understanding of networking amongst Indonesians, which underpins the management practice within intra- and inter-organizations. This may explain why Indonesians tend to have an ambiguous meaning when communicating with counterparts (Lewis, 2006). Foreign counterparts are often confronted with uncleared meanings, in which further scrutiny is needed to read between the lines. It is also expected that the kekeluargaan perspective will enable further revelations of other implications for businesses and management that may not have been appreciated by Western scholars. Areas such as business ethics, professionalism, and leadership are some of the elements in international management that can be of interest to investigate.

In terms of human resource management, the non-Indonesian leaders are advised to maintain harmony, conflict avoidance, and space, in order to manage Indonesian staff respectfully. Understanding the layers of the society and how to address Indonesian people appropriately can be an effective 'entrance' to kekeluargaan society. One must avoid classifying kekeluargaan as an 'unprofessional' mindset, in order not to lose loyalty, and to avoid 'unseen' disagreement in the organization. Overall, it is expected that this study can contribute as one of the primary sources of the Southeast Asian business paradigm.

\section{REFERENCES}

Allaire, Y., \& Firsirotu, M. E. (1984). Theories of organizational culture. Organization Studies, 5(3), 193-226.

Anderson, B. (1965). Mythology and the Tolerance of the Javanese. Modern Indonesia Project.

Anderson, B. (1990). Language and power: Exploring political cultures in Indonesia. Cornell University Press.

Baskerville, R. F. (2003). Hofstede never studied culture. Accounting, Organizations and Society, 28(1), 1-14.

Bertrand, R. (2015). Locating the 'Family-State': The Forgotten Legacy of Javanese Theories of the Public Domain (17th-20th C.). In M. M. Charrad \& J. Adams (Eds.), Patrimonial Capitalism and Empire (Vol. 28, pp. 241-265): Emerald Group Publishing Limited.

Bhopal, M., \& Hitchcock, M. (2001). Introduction: the culture and context of the ASEAN business crisis. Asia Pacific Business Review, 8(2), 1 - 18.

Chariri, A. (2008). Organisational Culture And Financial Reporting Practice in an Indonesian Insurance Company: Javanese Culture Perspective. Paper presented at the 3rd International Conference on Business and Management, Bali. 
Chariri, A. (2009). Ethical Culture and Financial Reporting: Understanding Financial Reporting Practice within Javanese Perspective. Issues in Social and Environmental Accounting, 3(1), 45-65.

Effendi, S. (2004). Sistem Pemerintahan Negara Kekeluargaan. Dies Natalis ke-18 Universitas Wangsa Mandala. Yogyakarta.

Efferin, S., \& Hartono, M. S. (2015). Management control and leadership styles in family business: An Indonesian case study. Journal of Accounting \& Organizational Change, 11(1), 130-159.

Efferin, S., \& Hopper, T. (2007). Management control, culture and ethnicity in a Chinese Indonesian company. Accounting, Organizations and Society, $32(3), 223-262$.

Fujimori, M. (1993). The Formation of "Uchi Society" in Japanese Business. Keio business review, 30, 1-9.

Geertz, C. (1973). The interpretation of cultures: Selected essays. New York: Basic books.

Geertz, H. (1961). The Javanese family: A study of kinship and socialization (Vol. 2): Free Press of Glencoe New York:.

Hofstede, G. (1980). Culture and organizations. International Studies of Management \& Organization, 10(4), 1541.

Horak, S. (2014). Antecedents and characteristics of informal relation-based networks in Korea: Yongo, Yonjul and Inmaek. Asia Pacific Business Review, 20(1), 78-108.

Horak, S., \& Taube, M. (2015). Same but different? Similarities and fundamental differences of informal social networks in China (guanxi) and Korea (yongo). Asia Pacific Journal of Management, 1-22.

Ip, P. K. (2009). Is Confucianism good for business ethics in China? Journal of Business Ethics, 88(3), 463-476.

Irawanto, D. W., Ramsey, P. L., \& Ryan, J. C. (2011a). Challenge of leading in Javanese culture. Asian Ethnicity, 12(2), 125-139.

Irawanto, D. W., Ramsey, P. L., \& Ryan, J. C. (2011b). Tailoring leadership theory to Indonesian culture. Global Business Review, 12(3), 355-366.

KBBI. (Ed.) (2005). Kamus besar bahasa Indonesia (Vols. third). Jakarta: Pusat Pembinaan dan Pengembangan Bahasa Departemen Pendidikan Nasional RI dan Balai Pustaka.

Keesing, R. M. (1974). Theories of culture. Annual Review of Anthropology, 3, 73-97.

Koentjaraningrat. (1984). Kebudayaan Jawa: Balai Pustaka. Langton, N., Robbins, S. P., \& Judge, T. A. (2013). Fundamentals of organizational behaviour. Pearson Education Canada.

LaVan, H., \& Murphy, P. J. (2007). Southeast Asian culture, human development, and business competitiveness. Journal of Asia Business Studies, 2(1), 14-22.

Lewis, R. D. (2006). When cultures collide: Leading across cultures (Third ed.). Boston: Nicholas Brealey International.

Li, P. P., Sekiguchi, T., \& Zhou, K. (2016). The emerging research on indigenous management in Asia. Asia Pacific Journal of Management, 33(3), 583-594.

Lin, L.-H. (2011). Cultural and organizational antecedents of guanxi: The Chinese cases. Journal of Business Ethics, 99(3), 441-451.

Magnis-Suseno, F. (1997). Javanese ethics and world-view: The Javanese idea of the good life. Jakarta: Gramedia Pustaka Utama.

Meyer, K. E. (2006). Asian management research needs more self-confidence. Asia Pacific Journal of Management, 23(2), 119-137.

Miles, M. B., \& Huberman, A. M. (1994). Qualitative data analysis: An expanded sourcebook (2nd ed.). London: Sage Publication.

Mulder, N. (2005). Mysticism in Java: ideology in Indonesia. Yogyakarta: Kanisius.

Oxford. (1989). Oxford English Dictionary. Oxford: Oxford university press.

Peoples, J., \& Bailey, G. (2011). Humanity: An introduction to cultural anthropology. Wadsworth Pub Co.

Perks, H., \& Sanderson, M. (2000). An international case study of cultural diversity and the role of stakeholders in the establishment of a European/Indonesian joint venture in the aerospace industry. Journal of Business \& Industrial Marketing, 15(4), 275-290.

Porsanger, J. (2004). An essay about indigenous methodology. Nordlit, 8(1), 105-120.

Rademakers, M. F. L. (1998). Market organization in Indonesia: Javanese and Chinese family business in the jamu industry. Organization Studies, 19(6), 1005-1027.

Rasuanto, B. (1999, 8 September 1999). Negara Kekeluargaan: Soepomo vs Hatta. Kompas Newspaper.

Sarwono, S. S., \& Armstrong, R. W. (2001). Microcultural differences and perceived ethical problems: An international business perspective. Journal of Business Ethics, 30(1), 41-56.

Schein, E. H. (1990). Organizational culture. American psychologist, 45(2), 109.

Selvarajah, C., \& Meyer, D. (2017). Human capacity development in Indonesia: leadership and managerial ideology in Javanese organizations. Asia Pacific Business Review, 23(2), 264-289.

Selvarajah, C., Meyer, D., Roostika, R., \& Sukunesan, S. (2016). Exploring managerial leadership in Javanese (Indonesia) organisations: engaging Asta Brata, the eight principles of Javanese statesmanship. Asia Pacific Business Review, 23(3), 373-395.

Shiraishi, S. (1997). Young heroes: The Indonesian family in politics (Vol. 22). SEAP Publications. 
Sitorus, S., \& Budhwar, P. S. (2003). Doing Business in Indonesia. Thunderbird International Business Review, 45(5), 587-609.

Smircich, L. (1983). Concepts of culture and organizational analysis. Administrative Science Quarterly, 339-358.

Storz, M. L. (1999). Malay and Chinese values underlying the Malaysian business culture. International Journal of Intercultural Relations, 23(1), 117-131.

Sunaryo, L. (2010). The Role Of Culture In Prescribing Beliefs And Practices For Achieving Success; Chinese Versus Javanese Managers In Indonesia Integritas Jurnal Manajemen Bisnis, 3(2), 117-144.
Thornton, P., Ocasio, W., \& Lounsbury, M. (2012). The institutional logics perspective: A new approach to culture, structure, and process. Oxford: Oxford University Press.

Tsui, A. S. (2004). Contributing to global management knowledge: A case for high quality indigenous research. Asia Pacific Journal of Management, 21(4), 491-513.

Wilson, S. (2001). What is an indigenous research methodology? Canadian Journal of Native Education, 25(2), 175-179. 